\title{
DETERMINANTS OF FINANCIAL INCLUSION IN SOUTHERN AFRICA
}

\author{
David MHLANGA* \\ University of Johannesburg, South Africa \\ Varaidzo DENHERE \\ University of Johannesburg, South Africa
}

\begin{abstract}
The study sought to establish the drivers of financial inclusion in Southern Africa with a specific focus on South Africa. Financial inclusion has been a topic of global interest due to the negative impact of financial exclusion in addressing socio-economic issues like poverty. Using the logit model, the study discovered that financial inclusion is driven by age, education level, the total salary proxy of income, race, gender, and marital status. The variable gender was the only factor with a negative influence on financial inclusion all other significant variables had a positive influence on financial inclusion. As a result, governments in Africa should encourage the use of financial services and products among women, Black Africans, Coloureds and the youths. Products and services tailor-made to satisfy the needs of these groups should be designed to improve financial inclusion among them. This initiative will go a long way in addressing poverty, inequality, and unemployment in the country.
\end{abstract}

JEL classification: G1, O12, G23, G38

Keywords: Africa; Financial Inclusion; Household Survey Data; Determinants South Africa

\section{Introduction}

Financial inclusion has become an attractive topic at the global level with governments, financial institutions, and policymakers, developing interest in understanding it more deeply (Amoah et al. 2020, Mhlanga et al. 2020). The existence of financial exclusion has been acknowledged by many developed and developing nations as one of the socio-economic challenges on the agenda (Sarma and Pais, 2011; Wentzel et al., 2016). The World Bank in its 2020 targets placed

\footnotetext{
${ }^{*}$ Corresponding author. Address: University of Johannesburg PO Box 524 Auckland Park, 2006 dmhlanga67@gmail.com. ORCID org/0000-0002-8512-2124
} 
universal financial access as one of its objective (Demirguc-Kunt et al., 2018, WBG, 2018). This shows how financial inclusion has become an attractive topic globally and more than 50 countries made headline financial inclusion commitments as of the end of 2014 (Louis and Chartier, 2017, Demirguc-Kunt et al., 2018) The World Bank Group (WBG) in 2017, clearly highlighted that many countries are developing National Financial Inclusion Strategies (NFIS) to ensure that resources and actions are put in place to achieve financial inclusion commitments. NFIS can be defined as roadmaps of actions, agreed and defined at the national or subnational level (WBG, 2017, WBG, 2018, Wentzel et al., 2016).

Moreover, financial inclusion is viewed as one of the strategies which can be put in place to achieve the goals of eliminating poverty unemployment and reducing inequality. The South African government through the National Development Plan Vision 2030, published in November 2011, aims to eliminate poverty, reducing inequality, and achieve full employment, decent work and sustainable livelihood, acknowledges financial inclusion as one of the important tools that will contribute toward the realization of its goals (Louis and Chartier, 2017, WBG, 2017). The South Africa government anticipates the proportion of the population that is banked or has access to transactional financial services and saving facilities to increase from about 63 per cent to about 90 per cent by 2030 (Louis and Chartier, 2017, WBG, 2017). The same document identifies as a priority to continuously broaden access to banking services to poorer people and lowering costs through a combination of competitive pressures and reducing other infrastructure costs (WBG, 2017, Louis and Chartier, 2017).

Empirical evidence that recognised financial inclusion as an instrument which can help to achieve financial development, economic growth, reduction in income inequality, and lifts households out of poverty is there for instance (Beck et al., 2009, Demirguc-Kunt and Levine, 2008, Demirguc-Kunt et al., 2018, Chibba, 2009). It is important to highlight that direct access and use of financial resources is not only the avenue through which financial inclusion can benefit people, but there are other indirect benefits associated with financial inclusion like consumption smoothening and being cushioned from shocks like natural disasters and other economics challenges (Cámara and Tuesta, 2018, Chibba, 2009). Empirically, scholars believe financial inclusion should be embraced as a complement to traditional ways of addressing social challenges like poverty and inequality (Chibba 2009, Mhlanga 2020a, Mhlanga 2020b).

Also, several scholars like Chibba (2009), Mhlanga and Dunga (2020) and Mhlanga et al. (2020) admit to the fact that the global development challenges, global financial crises and other unknown challenges that threaten human prosperity need a holistic approach in applying policies that improve financial inclusion. This is because financial inclusion is important not only in enhancing economic growth, which plays an essential role in lifting household above the poverty line, but it also helps close the gaps of income inequality (Beck et al., 2005, Beck et al., 2011). Demirguc-Kunt et al. (2018) argued that the role played by the financial sector in every economy is important and clear, The authors posit that financial sector promotes economic growth and development through financial intermediation by channelling funds from the surplus unit to the deficit unit of the economy. This is the direct role financial inclusion which can help to fight poverty and inequality through allowing households to invest in future, smoothen their consumption patterns and management of financial risks (Demirguc-Kunt et al., 2018, Beck et al., 2011). Even 
the smallest amounts of financial assets provide one with a cushion from economic shocks, as well as possible loss in income in later life. While, households who are financially excluded cannot partake in the different forms of saving or wealth accumulation, such as earning interest, making savings through paying bills via direct debit, or gaining favourable forms of credit (Chibba, 2009, Cámara and Tuesta, 2018, Sarma, 2012).

In South Africa, a study by Wentzel et al. (2016) found that the most significant factors associated with being financial exclusion were educational level, the primary source of income, age, home language and number of dependents. Similarly, in Zimbabwe Mhlanga and Dunga (2020) assessed the determinants of financial inclusion among smallholder farmers. The study concluded that off-farm income, the level of education, distance, financial literacy and age of the household head were the significant variables in explaining the determinants of financial inclusion among the smallholder farmers in Manicaland Province of Zimbabwe. Also, a study by Wokabi (2019) sought to analyse the underlying determinants of financial inclusion among five East African nations which include Kenya, Uganda, Tanzania, Rwanda and Burundi. The study found that rural population and income were the significant factors influencing financial inclusion. The study also found that unemployment had a negative influence on financial inclusion though insignificant. In another study, Prymostka et al., (2020) investigated the determinants of financial inclusion in Ukraine and found out that financial inclusion in is driven lack of funds among the citizens, distrust of banking institutions and unacceptable pricing policy of banks. Motivated by the importance of financial inclusion, the study sought to extends the literature on financial inclusion by investigating the determinants of financial inclusion in South Africa using the 2018 General Household Survey data (GHS).

\section{South Africa's Financial System}

South Africa's banking sector currently includes seventeen domestic commercial banks, two mutual banks, two cooperative banks, fourteen local branches of foreign banks, as well as representative offices of 43 foreign banks (Louis and Chartier, 2017, Wentzel et al., 2016). However, there are only four( Louis and Chartier 2017) while others put them at five( Louis and Chartier 2017 )major South African commercial banks who own and control more than 80 per cent of the banking sector's total assets, approximately 4 trillion Rand or US\$285 Billion (WBG, 2017, Louis and Chartier, 2017, Cessda et al., Riley, 2019). The banking infrastructure in South Africa is impressive, with a network of over 5,000 branches and nearly 30,000 ATM's (Louis and Chartier, 2017, Riley, 2019, Nanziri and Leibbrandt, 2018). The volume of electronic financial transactions (EFT) including debit card, credit card, and other on-line payments have increased in the country rising by 60 per cent between 2005 and 2013 (WBG, 2017, Louis and Chartier, 2017, Nanziri and Leibbrandt, 2018). According to Louis and Chartier (2017), the banking infrastructure and personnel in South Africa are concentrated in the Gauteng province, home of the country's economic capital Johannesburg and political capital Pretoria. The corporate headquarters of all major South African banks are in Johannesburg. In this regard, South Africa has made significant progress towards 
improving financial inclusion when compared with other global nations and regions. The table below shows a comparison of the financial inclusion of South Africa and selected global nations.

Table 1: South Africa Financial Inclusion Comparison with other Global Nations

\begin{tabular}{lccc}
\hline Country & $\begin{array}{c}\text { Accounts } \\
\text { (\% age 15+) }\end{array}$ & $\begin{array}{c}\text { Formal Savings } \\
(\% \text { age 15+) }\end{array}$ & $\begin{array}{c}\text { Formal Borrowings } \\
(\% \text { age 15+) }\end{array}$ \\
\hline South Africa & 70 & 33 & 12 \\
Sub-Saharan Africa & 34 & 16 & 6 \\
Eastern Europe \&Central Asia & 51 & 8 & 12 \\
World & 62 & 27 & 11 \\
\hline
\end{tabular}

Source: Louis and Chartier (2017)

On the surface, this data illustrates that South Africa's financial system is considerably more inclusive than Sub-Saharan Africa and more inclusive that Eastern Europe and Central Asia, as well as the world in general. However, this overall data hides a high level of inequalities in South Africa in terms of access to financial products and services. In the country, less than 30 per cent of low-income adults the poorest 25 per cent own a formal bank account as compared to 91 per cent of high-income adults the richest 25 per cent (Louis and Chartier, 2017, Wentzel et al., 2016). The problem exists, in part, because the South African banking industry is a highly concentrated source of wealth and limits access to capital to primarily the wealthy (Louis and Chartier, 2017, Nanziri and Leibbrandt, 2018, Riley, 2019). This imbalance in access to financial products and services between the wealthy individuals and the poor are shown in the table below which shows the amount of time taken to get to access point in South Africa.

Table 2: Time Taken to Get to a Financial Access Point

\begin{tabular}{lllll}
\hline Access point type & Total & Urban areas & Traditional areas & Farm areas \\
\hline ATM & $28: 10: 00$ & $20: 00$ & $47: 40: 00$ & $48: 20: 00$ \\
Petrol Station & $28: 30: 00$ & $20: 20$ & $49: 20: 00$ & $48: 00: 00$ \\
Supermarket & $28: 40: 00$ & $26: 50: 00$ & $34: 40: 00$ & $29: 10: 00$ \\
Post Office & $31: 50: 00$ & $24: 30: 00$ & $48: 30: 00$ & $51: 50: 00$ \\
Bank Branch & $34: 10: 00$ & $26: 20: 00$ & $53: 20: 00$ & $54: 10: 00$
\end{tabular}

Source: WBG (2017)

Table 2 shows the mean time taken to get to an actual or potential financial services access point depending on whether an individual resides in an urban, traditional or farm area. Except for supermarkets, people living in non-urban areas take twice as much time or even more to reach these access points than do people 
living in urban areas (WBG, 2017). The reality remains that currently, more than 12 million South African adults lack a basic bank account and millions more are underbanked, those with an existing, but the inactive bank. However, despite the challenges affecting the financial system in South Africa, overall, the banking services and payments infrastructure has a reasonably well-developed network of access points, making extensive use of technology in both enabling and extending the service reach. According to the Banking Association of South Africa, since 2010 more than 90 per cent of households in the country have access to a physical access point within a 10-kilometre radius (WBG, 2017). There are at least transactional access points from a regulated service provider in each of the 278 municipalities in the country (WBG, 2017). There is nevertheless room for improvement, particularly in rural areas.

The National Payment System Framework and Strategy Vision 2025 spelt out the need for financial inclusion through cooperation and collaboration among industry stakeholders in providing access and effective use of formal financial products for all South Africans (WBG, 2017, Louis and Chartier, 2017). In that same document, it is argued that financial inclusion remains one of the South African Reserve Bank (SARB)'s the priority (Wentzel et al., 2016, WBG, 2017, Louis and Chartier, 2017). In October 2015, the National Treasury of South Africa (NTS) sought from other relevant authority's comments on a draft, South African Financial Inclusion Policy and Policy Implementation document. The draft Policy includes, among its objectives, the promotion of improved and sustainable access to and usage of appropriate and affordable financial services (WBG, 2017, Louis and Chartier, 2017). Along with the draft Policy, the NTS consulted relevant authorities for a financial inclusion monitor report, aimed at improving the availability of financial inclusion data to enable monitoring, evidence-based policies and adjustment of initiatives if necessary (WBG, 2017, Louis and Chartier, 2017).

\section{Literature Review}

The empirical literature on the determinants of financial inclusion is available but limited. Zins et al., (2016) examined the determinants of financial inclusion in Africa. Using the World Bank's Global Findex database on 37 African countries the study found out that being a man who is rich with more education and older improves financial inclusion. The study also discovered that education and income had a higher influence on financial inclusion and that the determinants of informal finance were different from those of formal finance. Some of the findings by Zins et al., (2016) were supported by Sanderson et al. (2018) who investigated the determinants of financial inclusion in Zimbabwe. Sanderson et al.,(2018) discovered that age, education level, financial literacy, income and internet connectivity were the factors positively related to financial inclusion while documentation required to open a bank account and distance to the nearest access point were negatively related to financial inclusion.

In another study by Mhlanga and Dunga (2020) agreed with the findings by Sanderson et al., (2020). Mhlanga and Dunga (2020) assessed the level of financial inclusion among the smallholder farmers in Manicaland province of Zimbabwe. The 
study discovered that off-farm income, education level, distance, financial literacy and age of the household were the significant variables in explaining the determinants of financial inclusion among the smallholder farmers in Manicaland Province of Zimbabwe. Kaur et al., (2020) also examined the determinants of accessing institutional and non-institutional finance across male and female-headed households in rural India. Using the multinomial logistic regression, the study also discovered that education level is one of the important factors influencing financial inclusion. Other factors that were discovered were monthly household consumption expenditure, land size holding, access to irrigation land and the levels of scheduled penetration of commercial banks influenced financial inclusion.

Dar et al., (2020) also sought to investigate the determinants and barriers of financial inclusion in India. Using the Global Findex Database (Findex) of 2017, the study found out that gender, age, education and income influence financial inclusion with a significant influence on the informal saving and borrowing. Some of the results by Dar et al., (2020) were supported by Mhlanga and Dunga (2020). Gebrehiwot et al, (2019) also examined the determinants of financial inclusion across 27 Africa countries using the GMM dynamic panel data analysis. The study discovered that the lagged value of GDP per capita and mobile infrastructure positively influences financial inclusion while government borrowing had a negative influence on financial inclusion.

In South Africa, Wentzel et al. (2016) investigated the factors impacting financial exclusion at the bottom of the pyramid in South Africa. The study found out that, South Africa suffers from high levels of financial exclusion, disproportionately at the bottom of the pyramid. The study showed that the most significant factors associated with being financially excluded at the bottom of the pyramid in South Africa were educational level, the primary source of income, age, home language and number of dependents. The study further found that gender, relationship status and homeownership were not associated with being financially excluded. An interesting finding was that living in a rural area as opposed to an urban area was not significantly associated with being excluded. The following section will explain the methodology and data to achieve the objectives of the study.

\section{Methodology and Data}

Relevant data for the study were extracted from the South Africa 2018 General Household Survey (GHS) dataset. Relevant data for the study were extracted from the data set. Among the numerous variables in the data set, only important variables were selected for this study. Individuals who did not specify whether they had a bank account or not were removed from the analysis and those who did not know as well as those in the age group of 1-14 years who were regarded as dependence who cannot fully decide on whether to have a bank account not. $A$ total of 20000 individuals of the age group of $15-88$ was used in the study after removing the stated groups of individuals. The data were thereafter cleaned, recategorized and recoded, as necessary. The GHS target population consisted of all private households in all nine provinces of South Africa and residents in workers' hostels. 


\subsection{The Econometric Model}

The dependent variable is dichotomous, that is either an individual has a bank account or not represented by a 0 or 1 , respectively. The dependent variable is generated from the question which was asking questions on whether a person owns a bank account individually, jointly, or not. Those who owned bank accounts jointly were regarded as owners of bank accounts. As a result, the logit model was used in this study since the model has been widely used for the estimation of the choice model in most of the African countries and its advantages over other models. In Zimbabwe, for example, Sanderson et al. (2018). Kiplimo et al. (2015) investigated factors influencing access to credit among the smallholder farmers using the logit model estimation technique in Kenya. Moreover, since the dependent variable is binary, the three ways that can be used to investigate the determinants of financial inclusion are using the linear probability model, logit model and probit model. The linear probability model is an extension of the linear regression model to cases with the qualitative dependent variables. However, the research did not use the linear probability model because of weaknesses associated with the model.

The linear probability model produces dubious probability, it can be less than zero or greater than one which is unrealistic because probability should lie between zero and one. The error term normally suffers from the problem of heteroscedasticity and they are non-normal. Marginal effects will always be constant regardless of the value of Xi of the dummy variable (Gujarati, 2009, Cameron and Trivedi, 1986). This is mainly because it assumes a linear relationship between the dependent variable and the independent variable (Cameron and Trivedi, 1986). Due to the above weaknesses, the linear probability model was not used, the option available was the logit model or the probit model. However, the researcher used the logit model because of its advantages over the probit model. One of the advantages of the logit model is that it is relatively simple to calculate for the first-order conditions and is the asymptotic distribution (Rao et al., 1973). Also, Maddala et al. (2001) state that the model is simple to compute and interpret as compared to the probity model. Since we are dealing with the survey data logit model is appropriate than the probit model which is appropriate for the experimental data.

\subsubsection{The Logit Model}

The logit model is a method of estimation used in this study. The logit model takes the following model:

$$
\mathrm{P}=\mathrm{E}\left(\mathrm{Y}=1 / \mathrm{X}_{\mathrm{i}}\right)=1 /\left(1+\varepsilon\left(-\beta+\beta 2 \mathrm{xy}_{\mathrm{i}}\right)\right.
$$

Which can be further expressed as follows; $\mathrm{P}=\frac{1}{1+\mathrm{e}^{-\mathrm{z}}}=\frac{\mathrm{e}^{\mathrm{z}}}{1+\mathrm{e}^{\mathrm{z}}}$

Where $\mathrm{z}$ is expressed as:

$$
\mathrm{Z}_{\mathrm{i}}=\mathrm{f}\left(\beta_{\mathrm{i}}+\beta_{2} \mathrm{X}_{\mathrm{i}}\right)
$$

\subsubsection{Specification of The Model}

The model specification used in the study can be specified as follows: 
Financial Inclusion $=F$ (Race, Age, Highest Education Level, Gender, Marital Status, Total Salary). This can be expressed in a form where financial inclusion is given as $P$ (Financial Inclusion $1 / X$ ) is the probability that an individual has a bank account given the vector of the observable characteristics. The logistic function is given as $\mathrm{G}(\mathrm{z})$ as shown in equation 2 and 3 above. $\mathrm{G}(\mathrm{z})=\frac{\mathrm{e}^{2}}{1+\mathrm{e}^{2}}=P$ (Financial Inclusion $=$ $1 / \mathrm{x})$.

\subsubsection{Definition and Justification of the Variable}

Dependent variable: Financial Inclusion (FI) explained as bank account ownership. The dependent variable is a dichotomous dependent variable which takes value 1 when the individual has a bank account and 0 otherwise. The Independent variables included in the model include gender, age, race, marital status, and the highest education level. These variables were named as follows in the model. Dependent Variable is FI which is dichotomous, that is either an individual has a bank account or not represented by a 0 or 1 respectively, and independent variables are Gender, Age, Race, Marital status, Total salary Proxy of Income, Highest education level. The independent variables are explained in table one below.

Table 3: Description of Independent Variables

\begin{tabular}{|c|c|}
\hline \multirow[b]{2}{*}{ Variable } & \multirow[t]{2}{*}{ Description } \\
\hline & \\
\hline Gender & $\begin{array}{l}\text { Is a dummy variable where } 1=\text { male and } 0 \text { otherwise? The } \\
\text { variable is expected to be }+ \text {. }\end{array}$ \\
\hline Age & $\begin{array}{l}\text { Is a continuous variable which explains the number of years the } \\
\text { individual has? The variable is expected to be }+\end{array}$ \\
\hline Race & $\begin{array}{l}\text { Is a categorical variable which explains the grouping of humans } \\
\text { based on shared physical or social qualities? In this variable } \\
1=\text { African Black, } 2=\text { Colored, } 3=\text { Indian/Asian, } 4=\text { White. The } \\
\text { variable is expected to be }-/+ \text { depending on the reference } \\
\text { category in the dummy variable. }\end{array}$ \\
\hline $\begin{array}{l}\text { Marital } \\
\text { status }\end{array}$ & $\begin{array}{l}\text { Explains whether the individual is married or not, where } 1= \\
\text { legally married and } 0 \text { otherwise. The variable is expected to be } \\
+\end{array}$ \\
\hline Total salary & $\begin{array}{l}\text { Is the total amount of Income Received by the Individual which } \\
\text { act as a proxy of Income? The variable is expected to have a } \\
\text { positive }(+) \text { influence on financial inclusion. }\end{array}$ \\
\hline $\begin{array}{l}\text { Highest } \\
\text { education } \\
\text { level }\end{array}$ & $\begin{array}{l}\text { Refers to the level of education of the individuals expected to } \\
\text { have a positive }(+) \text { influence on financial inclusion }\end{array}$ \\
\hline
\end{tabular}

Source: Author's Analysis 


\section{Presentation and Interpretation of Results}

The results from the estimation of the drivers of financial inclusion using the logit model are presented in Table 4.

Table 4: Determinants of financial inclusion-logit estimates

\begin{tabular}{lllllll}
\hline Variable & B & S.E. & Wald & Df & Sig. & Exp(B) \\
\hline Race & & & 741.554 & 3 & .000 & \\
Race (1) & .363 & .040 & 84.278 & 1 & .000 & 1.437 \\
Race (2) & 1.210 & .336 & 12.937 & 1 & .000 & 3.354 \\
Race (3) & 2.264 & .085 & 706.775 & 1 & .000 & 9.626 \\
Marital status (1) & .863 & .049 & 315.236 & 1 & .000 & 2.370 \\
Highest & .013 & .001 & 329.490 & 1 & .000 & .987 \\
education level & & & & & & \\
Total salary & .001 & .000 & 898.259 & 1 & .000 & 1.001 \\
Gender (1) & -.136 & .036 & 13.956 & 1 & .000 & .873 \\
AGE & .037 & .001 & 1459.59 & 1 & .000 & 1.038 \\
Constant & -1.835 & .043 & 1822.95 & 1 & .000 & .160 \\
& & & 1 & & & \\
\hline
\end{tabular}

Omnibus tests of model coefficients Chi-square step 8429.185, Block 8429.185, Model 8429.185, df 8, Sig 0.000. Model Summary, -2 Log likelihood 18920.143a, Cox \& Snell R Square 0.345, Nagelkerke R Square 0.462 .

Source: Author's calculations GHS data

\subsection{Discussion of Results}

The results from the estimation of the drivers of financial inclusion in South Africa from the 2018 GHS data using the logit model are presented in table 4. The model is free from multicollinearity since all the independent variables had a Pearson product-moment correlation coefficient, with a value of less than 0.8 in absolute terms. Kennedy (2003) outline that, for non-continuous variables, a value of 0.8 and above in absolute terms in one of the correlation coefficients indicates a high correlation between two independent variables. Concerning the overall results of the model, the results showed that there is a positive relationship between race, age, marital status, total salary and highest education level and financial inclusion. On the other hand, gender with males as a reference category had a negative relationship with financial inclusion.

The results show a positive and significant relationship between race and financial inclusion. The coefficient race was significant at all levels with a significant value of 0.000 for all the races with Black African as the reference category. Among 
the four races in South Africa, whites had a higher probability of demand for financial products compared to Black Africans, Coloureds and Indians/Asians. The odds of demand for financial products such as having a bank account is 9.626 higher for whites compared to African Blacks, Indians/Asians and Coloureds. Also, Indians/Asians have a higher probability of demand for financial products compared to Coloureds and African Blacks. The odds of demand for financial products for Indians was 3.354 higher for Indians compared to Coloureds who had 1.437 odds of demand for financial products higher than African Black. Black African had the least odds of demand for a financial product, that is the probability of demand for financial products and services is low among the black compared to other races like whites Coloureds and Indians/Asians.

The study also shows that marital status is a positive significant impact on financial inclusion. The variable was significant at all level with a significant value of 0.000 . The results went on to reveal that, the odds of demand for financial products like a bank account is 2.370 higher for married individuals compared to those who are not married. Married people have a higher likelihood of demand for financial products and services compared to individuals who are not married. The study also revealed that education had a positive significant influence on financial inclusion. According to Sanderson et al. (2018), educated people can quickly comprehend the various financial products on the market. This increases their likelihood of participating in the formal financial market. This was supported by Kempson (2000), Berthoud and Kempson (1992) and Kempson (1994). These studies agreed to the fact that educated people easily comprehend the various financial products, which increases the chances of them participating in the financial market. Louis and Chartier (2017) discovered that residence, age, education level, and gender determine account ownership and ninety-four per cent of adults with a college degree own a bank account as compared to only 43 per cent of those with only primary education in South Africa.

The results also showed that total salary a proxy of total income for individuals had a positive significant impact on financial inclusion. As people's income increases financial inclusion also increase. This results in the South African context makes sense because people who earn an income are paid through the bank. In fact, due to high crime risk, even those who work in the informal sector are paid through the bank. This was supported by Sanderson et al. (2018) who discovered that income influences the level of financial inclusion in Zimbabwe.

The study also showed that the age of the individual has a positive significant impact on financial inclusion. As people grow, they tend to understand the importance of financial products and services compared to the young, this will lead them to use more of these services and products. This was supported by several studies (Sanderson et al., 2018, Masiyandima et al., 2017). The results also showed a negative and significant relationship between gender and financial inclusion. In this case, gender was significant at all levels. The meaning of the negative sign on gender implied that access to financial products and services decline as far as women are concerned. This result is in line with the idea that males are the heads of households in many family setups in South Africa. Males being the reference category, the results indicated that demand for financial products is higher for males compared to females. This was supported by Sanderson et al. (2018), Kempson (2000) who found males to have a higher demand for financial products compared to female. 


\section{Conclusion}

The South African government is committed to improving financial inclusion and has since recognised the importance of financial inclusion in the NDP vision 2030 where the government envisage the proportion of the population that is banked or has access to transactional financial services and saving facilities to increase from about 63 per cent to about 90 per cent by 2030 . Also, the African government came up with the South African Financial Inclusion Policy and Policy Implementation document. The draft Policy which included, among its objectives, the promotion of improved and sustainable access to and usage of appropriate and affordable financial services. Given the government's commitment towards financial inclusion and the encouraging statistics showing improvement in key financial inclusion indicators, the study sought to establish the drivers of financial inclusion in South Africa. In line with the objective, the study has established that financial inclusion is driven by age, education, the total salary proxy of income, race, gender, and marital status. Of these results age, education, the total salary proxy of income, race, and marital status are positively related to financial inclusion. This implies that an increase in any of these variables significantly increases the level of financial inclusion in South Africa.

On the other hand, being female in South Africa reduces the chances of people being financial included. Therefore, the government should encourage the use of financial services among women, products and services should be designed tailor-made to satisfy the needs of women. The differences in the probability of demand among the different races in South Africa shows us that, there is need for massive financial education among the other races with lower probability of demand for financial products of the benefits of financial inclusion. Since the level of education proves to improve the level of financial inclusion the government needs to ensure that, education is intensified of the people in South Africa so that they will find it good to participate in the financial sector. This will allow the government to achieve the vision 2030 articulated through the National Development Plan vision 2030, published in November 2011, aimed at eliminating poverty, reducing inequality, and achieve full employment, decent work, and sustainable livelihood. Therefore, policymakers, governments and development agencies must consider the following factors race, age, marital status, total salary, highest education level and gender financial inclusion in their efforts to address the problem of financial exclusion and quest to fight poverty among some sections of the community. The study was concentrated on Southern Africa mainly the SADC region with a deep analysis of South Africa due to data limitations. Extending the study to all the countries in Africa with a comparison to other regions like East Africa could have been more academically through the undertaking. Areas of further research may include a deeper analysis of the determinants of financial inclusion across different regions in Africa to compare the results. 


\section{References}

Amoah, A., Korle, K. and Asiama, R.K. 2020. Mobile money as a financial inclusion instrument: what are the determinants? International Journal of Social Economics. Emerald Group Publishing, vol. 47(10), pages 1283-1297, August.

Beck, T., Demirgüç-Kunt, A. \& Honohan, P. 2009. Access to financial services: Measurement, impact, and policies. The World Bank Research Observer, 24, 119-145.

Beck, T., Demirgüç -Kunt, A. \& Martinez Peria, M. S. 2005. Reaching out: Access to and use of banking services across countries, The World Bank.

Beck, T., Demirgüç-Kunt, A. \& Pería, M. S. M. 2011. Bank financing for SMEs: Evidence across countries and bank ownership types. Journal of Financial Services Research, 39, 35-54.

Berthoud, R. \& Kempson, E. 1992. Credit and debt. Policy Studies Institute, London.

Cámara, N \& Tuesta, D 2018. "Measuring financial inclusion: a multidimensional index," IFC Bulletins chapters, in: Bank for International Settlements (ed.), The role of data in supporting financial inclusion policy, volume 47, Bank for International Settlements.

Cameron, A. C. \& Trivedi, P. K. 1986. Econometric models based on count data. Comparisons and applications of some estimators and tests. Journal of applied econometrics, 1, 29-53.

Cessda, H. L. H., Eric, S. B. E., NSD, G. H. C., Cessda, J. K., NSD, M. M. C., Nidi, T. E. \& Cessda, D. B. This project has received funding from the European Union's Horizon 2020 research and innovation programme under grant agreement No 654221.

Chibba, M. 2009. Financial inclusion, poverty reduction and the millennium development goal. The European Journal of Development Research, 21, 213-230.

Dar, A.B. and Ahmed, F., 2020. Financial inclusion determinants and impediments in India: insights from the global financial inclusion index. Journal of Financial Economic Policy.

Demirguc-kunt, A., Klapper, L., Singer, D., Ansar, S. \& Hess, J. 2018. The Global Findex Database 2017: Measuring Financial Inclusion and the Fintech Revolution, The World Bank.

Demirguc-kunt, A. \& Levine, R. 2008. Finance, financial sector policies, and longrun growth, The World Bank.

Gebrehiwot, K.G. and Makina, D., 2019. Macroeconomic determinants of financial inclusion: Evidence using dynamic panel data analysis. In Extending Financial Inclusion in Africa (pp. 167-191). Academic Press.

Gujarati, D. N. 2009. Basic econometrics, Tata McGraw-Hill Education.

Kempson, E. 1994. Outside the banking system. Policy Studies Institute, London.

Kempson, E. 2000. In or out? Financial exclusion: Literature and research review, Financial Services Authority.

Kennedy, P. 2003. A guide to econometrics, MIT press.

Kaur, S. and Kapuria, C., 2020. Determinants of financial inclusion in rural India: does gender matter? International Journal of Social Economics.

Louis, L. \& Chartier, F. 2017. Financial Inclusion in South Africa: An Integrated Framework for Financial Inclusion of Vulnerable Communities in South Africa's Regulatory System Reform. Journal of Comparative Urban Law and Policy, 1, 13. 
Maddala, G., LI, H. \& Srivastava, V. 2001. A comparative study of different shrinkage estimators for panel data models. Annals of Economics and Finance, 2, 130.

Masiyandima, N., Mlambo, K. \& Nyarota, S. Financial Inclusion and Quality of Livelihood in Zimbabwe. 14th African Finance Journal Conference-Africa growth Institute, 2017.

Mhlanga, D., 2020a. Financial inclusion and poverty reduction: evidence from small scale agricultural sector in Manicaland Province of Zimbabwe (Doctoral dissertation, North-West University (South Africa)).

Mhlanga, D. 2020b. Artificial Intelligence (Al) and Poverty Reduction in the Fourth Industrial Revolution (4IR). https://doi.org/10.20944/preprints202009.0362.v1

Mhlanga, D, \& Dunga, S. H. (2020). Measuring Financial Inclusion and Its Determinants Among the Smallholder Farmers in Zimbabwe: An Empirical Study. Eurasian Journal of Business and Management, 8(3), 266-281. https://doi.org/10.15604/ejbm.2020.08.03.008

Mhlanga, David, Henry Dunga, S., \& Moloi, T. 2020. Financial Inclusion and Poverty Alleviation Among Smallholder Farmers in Zimbabwe. Eurasian Journal of Economics and Finance, 8(3), 168-182. https://doi.org/10.15604/ejef.2020.08.03.004

Nanziri, E. L. \& Leibbrandt, M. 2018. Measuring and profiling financial literacy in South Africa. South African Journal of Economic and Management Sciences, 21, 1-17.

Prymostka, L. O., Krasnova, I., Prymostka, O., Nikitin, A., \& Shevaldina, V. 2020. Financial inclusion in Ukraine: determinants and evaluation. Financial and credit activity: problems of theory and practice, 2(33), 500-512.

Rao, C. R., Rao, C. R., Statistiker, M., RAO, C. R. \& RAO, C. R. 1973. Linear statistical inference and its applications, Wiley New York.

Riley, T. A. 2019. South Africa: reducing financial constraints to emerging enterprises.

Sanderson, A., Mutandwa, L. \& Le Roux, P. 2018. A Review of Determinants of Financial Inclusion. International Journal of Economics and Financial Issues, $8,1$.

Sarma, M. 2012. Index of Financial Inclusion-A measure of financial sector inclusiveness. Money, Trade, Finance, and Development Competence Center in cooperation with DAAD Partnership and Hochschule für Technik und Wirschaft Berlin University of Applied Sciences. Working Paper.

Sarma, M. \& Pais, J. 2011. Financial inclusion and development. Journal of international development, 23, 613-628.

STATS SA, S. S. A. 2018. General Household Survey. In: STATISTICS (ed.). 28 May 2019: Government of South Africa.

WBG, T. W. B. G. 2017. Achieving effective financial inclusion in South Africa: a payments perspective. In: Finance, M. O. (ed.). South Africa: Government of South Africa.

WBG, W. B. G. 2018. UFA2020 Overview: Universal Financial Access by 2020. October 1, 2018 ed. HEADQUARTERS the World Bank $1818 \mathrm{H}$ Street, NW Washington, DC 20433 USA, World Bank Group. 
WentzeL, J. P., Diatha, K. S. \& Yadavalli, V. S. S. 2016. An investigation into factors impacting financial exclusion at the bottom of the pyramid in South Africa. Development Southern Africa, 33, 203-214.

Wokabi, V. W. 2019. Determinants of financial inclusion in East Africa International Journal of Business and Management, International Institute of Social and Economic Sciences, vol. 7(1), pages 125-143, May.

Zins, A. and Weill, L., 2016. The determinants of financial inclusion in Africa. Review of Development Finance, 6(1), pp.46-57. 